\title{
A Study of Exchange Rates Movement and Stock Market Volatility
}

\author{
Dr. Gaurav Agrawal \\ Assistant Professor \\ ABV-Indian Institute of Information Technology and Management, Gwalior, India \\ Tel: 91-751-244-9805Ｅ-mail: gaurav@iiitm.ac.in \\ Aniruddh Kumar Srivastav (Corresponding author) \\ ABV-Indian Institute of Information Technology and Management Gwalior, India \\ Tel: 91-920-227-6324Ｅ-mail: aniruddhiiitm@gmail.com
}

Ankita Srivastava

ABV-Indian Institute of Information Technology and Management Gwalior, India

Tel: 91-989-355-1550 E-mail: ankita.srivastava93@gmail.com

\begin{abstract}
This paper analyzes the relationship between Nifty returns and Indian rupee-US Dollar Exchange Rates. Several statistical tests have been applied in order to study the behavior and dynamics of both the series. The paper also investigates the impact of both the time series on each other. The period for the study has been taken from October, 2007 to March, 2009 using daily closing indices. In this study, it was found that Nifty returns as well as Exchange Rates were non-normally distributed. Through unit root test, it was also established that both the time series, Exchange rate and Nifty returns, were stationary at the level form itself. Correlation between Nifty returns and Exchange Rates was found to be negative. Further investigation into the causal relationship between the two variables using Granger Causality test highlighted unidirectional relationship between Nifty returns and Exchange Rates, running from the former towards the latter.
\end{abstract}

Keywords: Stock return, Exchange Rate, Unit root test, Correlation Test, Granger causality

\section{Introduction}

Many factors, such as enterprise performance, dividends, stock prices of other countries, gross domestic product, exchange rates, interest rates, current account, money supply, employment, their information etc. have an impact on daily stock prices (Kurihara, 2006: p.376).The issue of inter temporal relation between stock returns and exchange rates has recently preoccupied the minds of economists, for theoretical and empirical reasons, since they both play important roles in influencing the development of a country's economy. In addition, the relationship between stock returns and foreign exchange rates has frequently been utilized in predicting the future trends for each other by investors. Moreover, the continuing increases in the world trade and capital movements have made the exchange rates as one of the main determinants of business profitability and equity prices (Kim, 2003). Exchange rate changes directly influence the international competitiveness of firms, given their impact on input and output price (Joseph, 2002). Basically, foreign exchange rate volatility influences the value of the firm since the future cash flows of the firm change with the fluctuations in the foreign exchange rates. When the Exchange rate appreciates, since exporters will lose their competitiveness in international market, the sales and profits of exporters will shrink and the stock prices will decline. On the other hand, importers will increase their competitiveness in domestic markets. Therefore, their profit and stock prices will increase. The depreciation of exchange rate will make adverse effects on exporters and importers. Exporters will have advantage against other countries' exporters and increase their sales and their stock prices will be higher (Yau and Nieh, 2006). That is, currency appreciation has both a negative and a positive effect on the domestic stock market for an export-dominant and an import-dominated country, respectively (Ma and Kao, 1990). Exchange rates can affect stock prices not only for multinational and export-oriented firms but also for domestic firms. For a multinational company, changes in exchange rates will result in an immediate change in value of its foreign operations as well as a continuing change in the profitability of its foreign operations reflected in successive income statements. Therefore, the changes in economic value of firm's foreign operations may influence stock prices. Domestic firms can also be influenced by changes in exchange rates since they may import a part of their 
inputs and export their outputs. For example, a devaluation of its currency makes imported inputs more expensive and exported outputs cheaper for a firm. Thus, devaluation will make positive effect for export firms (Aggarwal, 1981) and increase the income of these firms, consequently, boosting the average level of stock prices (Wu, 2000). Thus, understanding this relationship will help domestic as well as international investors for hedging and diversifying their portfolio. Also, fundamentalist investors have taken into account these relationships to predict the future trends for each other (Phylaktis and Ravazzolo, 2005; Mishra et al., 2007; Nieh and Lee, 2001; Stavárek, 2005).

Globalization and financial sector reforms in India have ushered in a sea change in the financial architecture of the economy. In the contemporary scenario, the activities in the financial markets and their relationships with the real sector have assumed significant importance. Since the inception of the financial sector reforms in the beginning of 1990's, the implementation of various reform measures have brought in a dramatic change in the functioning of the financial sector of the economy. Floating exchange rate that has been implemented in India since 1991, facilitates greater volume of trade and high volatility in equity as well as Forex market, increasing its exposure to economic and financial risks. The relationship between the two financial variables-stock returns and exchange rates- became especially significant in the wake of the 1997 economic crisis in Asian countries, which caused stock prices and exchange rate to fall across Asian markets. It has been suggested that difference in expected stock returns should be related to changes in exchange rates. Moreover, in the recent years, because of increasing international diversification, cross-market return correlations, gradual abolishment of capital inflow barriers and foreign exchange restrictions or the adoption of more flexible exchange rate arrangements in emerging and transition countries, these two markets have become significantly interdependent. These changes have increased the variety of investment opportunities as well as the volatility of exchange rates and risk of investment decisions and portfolio diversification process. Altogether, the whole gamut of institutional reforms concomitant to globalization programme, introduction of new instruments, change in procedures, widening of network of participants call for a re-examination of the relationship between the stock market and the foreign sector of India. Correspondingly, researches are also being conducted to understand the current working of the economic and the financial system in the new scenario. Interesting results are emerging particularly for the developing countries where the markets are experiencing new relationships which are not perceived earlier. Although, economic theory suggests that foreign exchange changes can have an important impact on the stock price by affecting cash flow, investment and profitability of firms, there is no consensus about these relationship and the empirical studies of the relationship are inconclusive (Joseph, 2002; Vygodina, 2006).

The present study is an endeavor to analyze the relationship between stock prices volatility and exchange rates movement in India. The analysis on stock markets has come to the fore since this is the most sensitive segment of the economy and it is through this segment that the country's exposure to the outer world is most readily felt. This paper attempts to examine how changes in exchange rates and stock prices are related to each other over the period October 2007-March 2009. This period is marked by a bearish run on the stock market. The organization of the paper is done as follows: Section 2 contains a brief literature review. Methodology and empirical results are presented in Section 3 and 4 respectively. Concluding remarks take place in Section 5.

\section{Literature Review}

The existence of a relationship between stock prices and exchange rate has received considerable attention. Early studies (Aggarwal, 1981; Soenen and Hennigar, 1988) in this area considered only the correlation between the two variables-exchange rates and stock returns. Theory explained that a change in the exchange rates would affect a firm's foreign operation and overall profits which would, in turn, affect its stock prices, depending on the multinational characteristics of the firm. Conversely, a general downward movement of the stock market will motivate investors to seek for better returns elsewhere. This decreases the demand for money, pushing interest rates down, causing further outflow of funds and hence depreciating the currency. While the theoretical explanation was clear, empirical evidence was mixed. It was Maysami-Koh(2000), who examined the impacts of the interest rate and exchange rate on the stock returns and showed that the exchange rate and interest rate are the determinants in the stock prices. It was in 1992 that Oskooe and Sohrabian used Cointegration test for the first time and concluded bidirectional causality but no long term relationship between the two variables. Najang and Seifert(1992), employing GARCH framework for daily data from the U.S, Canada, the UK, Germany and Japan, showed that absolute differences in stock returns have positive effects on exchange rate volatility. Ajayi and Mougoué in 1996 picked daily data from 1985 to 1991 for eight advance economic countries; employed error correction model and causality test and eventually discovered that increase in aggregate domestic stock price has a negative short-run effect and a positive long-run effect on domestic currency value. On the other hand, currency depreciation has both negative short-run and long-run effect on the stock market. Abdalla and 
Murinde(1997) used data from 1985 to 1994, giving results for India, Korea and Pakistan that suggested exchange rates Granger cause stock prices. But, for the Philippines the stock prices lead the exchange rates. Furthering into Indian context, work in this area for the Indian Economy has not progressed much. Abhay Pethe and Ajit Karnik (2000) has investigated the inter - relationships between stock prices and important macroeconomic variables, viz., exchange rate of rupee vis - a -vis the dollar, prime lending rate, narrow money supply, and index of industrial production. The analysis and discussion are situated in the context of macroeconomic changes, especially in the financial sector, that have been taking place in India since the early 1990s. There are some other related studies though not specifically focused to this aspect. Studies like Agarwal, 1997; Chakrabarti, 2001; and Trivedi \& Nair, 2003, though, have shown that equity return has positive impact on FII. In 1998, Ajayi et al. investigated the causal relations for seven advanced markets from 1985 to 1991 and eight Asian emerging markets from 1987 to 1991 and supported unidirectional causality in all the advanced economies but no consistent causal relations in the emerging economies. They explained the different results by the differences in the structure and characteristics of financial markets between these groups. Morley and Pentecost (2000) conducted a study on G-7 countries, finally stating that the reason for the lack of 7 strong relationships between exchange rates and stock prices may be due to the exchange controls that were in effect in the 1980s. Similarly, Nieh and Lee in 2001 examined the relationship between stock prices and exchange rates for G-7 countries for the period from October 1, 1993 to February 15, 1999. They claimed no long-run equilibrium relationship for each G-7 countries. While one day's short-run significant relationship has been found in certain G-7 countries, there is no significant correlation in the United States. These results might be explained by each country's differences in economic stage, government policy, expectation pattern, etc. In 2003, Kim showed that S\&P's common stock price is negatively related to the exchange rate. Contemporarily, Smyth and Nandha studied the relationship for Pakistan, India, Bangladesh and Sri Lanka over the period 1995-2001 and proved no long run relationship between variables. Unidirectional causality was seen running from exchange rates to stock prices for only India and Sri Lanka. Also, Ibrahim and Aziz analyzed dynamic linkages between the variables for Malaysia, using monthly data over the period 1977-1998 and their results showed that exchange rate is negatively associated with the stock prices. Results that came from Gordon \& Gupta in 2003 and Babu and Prabheesh in 2007 claimed bidirectional causality stating that foreign investors have the ability of playing like market makers given their volume of investments.

Again in 2004, Griffin stated foreign flows are significant predictor of returns in Thailand, India, Korea, Taiwan and in 2005, Doong et al. showed that these financial variables are not cointegrated. Bidirectional causality could be detected in Indonesia, Korea, Malaysia and Thailand and significantly negative relation between the stock returns and the contemporaneous change in the exchange rates for all countries except Thailand.Ozair(2006) and Vygodina(2006) worked with US data. While Ozair proved no causal linkage and no Cointegration between these two financial variables, the latter claimed causality from large-cap stocks to exchange rates. Kurihara(2006) takes Japanese stock prices, U.S. stock prices, exchange rate, Japanese interest rate etc.(period March 2001-September 2005). The results showed that exchange rate and U.S. stock prices affected Japanese stock prices. Consequently, the quantitative easing policy implemented in 2001 has influenced Japanese stock prices. Pan et al. (2007) employed data of seven East Asian countries over the period 1988 to 1998, proving bidirectional causal relation for Hong Kong before the 1997 Asian crises and unidirectional causal relation from exchange rates and stock prices for Japan, Malaysia, and Thailand and from stock prices to exchange rate for Korea and Singapore. During the Asian crises, only a causal relation from exchange rates to stock prices is seen for all countries except Malaysia. Contemporarily, Erbaykal and Okuyan studied 13 developing economies, using different time periods and indicated causality relations for eight economies-unidirectional from stock price to exchange rates in the five of them and bidirectional for the remaining three. No causality was detected in Turkey; the reason of difference may be the time period used. However, Sevuktekin and Nargelecekenler found bidirectional causality between the two financial variables in Turkey, using monthly data from 1986 to 2006.Again, Takeshi(2008) showed unidirectional causality from stock returns to FII flows, irrelevant of the sample period in India where as the reverse causality works only post 2003.

To summarize, even though the theoretical explanation may seem obvious at times, empirical results have always been mixed and existing literature is inconclusive on the issue of causality. This paper attempts to investigate into the causal relationship between the two variables. The period of the study has been taken from October 2007-March 2009. Time period up to 2009 is taken to investigate the global crisis and its effect on the dynamics in Indian stock market. Also the analysis is based on the broader-based National Stock Exchange Index, Nifty, composed of 50 stocks. The NSE has outstripped the BSE in terms of turnover, efficiency and transaction costs; providing more liquidity and depth to trading. With strong preference of FIIs for holding shares of large firms and more liquid stocks, the NSE Nifty appears a more reasonable index to work on than the BSE Sensex. 


\section{Data \& Methodology}

The present study is directed towards studying the dynamics between stock returns volatility and exchange rates movement. We focus our study towards Nifty returns and Indian Rupee-US Dollar Exchange Rates. The frequency of data is kept at daily level and time span of study is taken from October 11, 2007 to March 9, 2009. The results from daily data are more precise and are better able to capture the dynamics between exchange rates and Nifty index. The data consists of - i) daily closing prices of the Nifty index , used to compute stock returns and ii) Indian Rupee/US Dollar ratios on a daily basis, used to compute exchange rates. The daily returns and exchange rates have been matched by calendar date. Data has been taken from Yahoo! Finance (www.yahoofinance.com) and Oanda, the currency site, (www.oanda.com/convert/fxhistory ). Line plots of the two time series-namely, Nifty returns and Exchange Rates- are shown in Fig 3.1 and 3.2 respectively.

Daily stock returns have been calculated by taking the natural logarithm of the daily closing price relatives, i.e. $\mathrm{r}$ $=\ln \mathrm{P}(\mathrm{t}) / \mathrm{P}(\mathrm{t}-1)$, where $\mathrm{P}(\mathrm{t})$ is the closing price of the $\mathrm{t}^{\text {th }}$ day. Similarly, natural logarithm of the daily exchange rate relatives have been computed as $\ln \mathrm{E}(\mathrm{t}) / \mathrm{E}(\mathrm{t}-1)$. The values so obtained have been employed for studying the relationship between stock returns and exchange rates. Line plots of the two, so obtained, normalized series are shown in Fig 4.1 and 4.2 respectively.

After reviewing the existing literature, following hypotheses are formulated in order to study the behavior of the two variables and were then put on test for the collected data to address the objective of the study:

Hypothesis 1: Stock returns and exchange rates are not normally distributed.

Hypothesis 2: Unit Root exists (i.e. non stationarity) in both the series.

Hypothesis 3: Correlation exists between the two variables-Stock returns and Exchange rates.

Hypothesis 4: No Causality exists between stock returns and exchange rates.

Following methods/tools are used to test the above hypotheses and subsequently draw inferences about the behavior and dynamics of the two variables. The tests- namely, the JB Test, Correlation test, Unit root test and Granger Causality test- were conducted with the aid of Eviews software (version 4.0).

\subsection{Normality Test}

The Jarque-Bera (JB) test [Gujarati (2003)] is used to test whether stock returns and exchange rates individually follow the normal probability distribution. The JB test of normality is an asymptotic, or large-sample, test. This test computes the skewness and kurtosis measures and uses the following test statistic:

$\mathrm{JB}=\mathrm{n}\left[\mathrm{S}^{2} / 6+(\mathrm{K}-3)^{2} / 24\right]$

Where $\mathrm{n}=$ sample size, $\mathrm{S}=$ skewness coefficient, and $\mathrm{K}=$ kurtosis coefficient. For a normally distributed variable, $\mathrm{S}=0$ and $\mathrm{K}=3$. Therefore, the $\mathrm{JB}$ test of normality is a test of the joint hypothesis that $\mathrm{S}$ and $\mathrm{K}$ are 0 and 3 respectively.

\subsection{Unit Root Test (Stationarity Test)}

Empirical work based on time series data assumes that the underlying time series is stationary. Broadly speaking a data series is said to be stationary if its mean and variance are constant (non-changing) over time and the value of covariance between two time periods depends only on the distance or lag between the two time periods and not on the actual time at which the covariance is computed [Gujrati (2003)].A unit root test has been applied to check whether a series is stationary or not. Stationarity condition has been tested using Augmented Dickey Fuller (ADF) [Dickey and Fuller (1979, 1981), Gujarati (2003), Enders (1995)].

\subsection{Augmented Dickey-Fuller (ADF) Test}

Augmented Dickey-Fuller (ADF) test has been carried out which is the modified version of Dickey-Fuller (DF) test. ADF makes a parametric correction in the original DF test for higher-order correlation by assuming that the series follows an AR (p) process. The ADF approach controls for higher-order correlation by adding lagged difference terms of the dependent variable to the right-hand side of the regression. The Augmented Dickey-Fuller test specification used here is as follows:

$\Delta \mathrm{Y}_{\mathrm{t}}=\mathrm{b}_{0}+\beta \mathrm{Y}_{\mathrm{t}-1}+\mu_{1} \Delta \mathrm{Y}_{\mathrm{t}-1}+\mu_{2} \Delta \mathrm{Y}_{\mathrm{t}-2}+\ldots . .+\mu_{\mathrm{p}} \Delta \mathrm{Y}_{\mathrm{t}-\mathrm{p}}+\mathrm{e}_{\mathrm{t}}$

$Y_{t}$ represents time series to be tested, $b_{0}$ is the intercept term, $\beta$ is the coefficient of interest in the unit root test, $\mu_{\mathrm{i}}$ is the parameter of the augmented lagged first difference of $Y_{t}$ to represent the $p^{\text {th }}$-order autoregressive process, and $\mathrm{e}_{\mathrm{t}}$ is the white noise error term. 


\subsection{Granger Causality Test}

According to the concept of Granger's causality test $(1969,1988)$, a time series $x_{t}$ Granger-causes another time series $y_{t}$ if series $y_{t}$ can be predicted with better accuracy by using past values of $x_{t}$ rather than by not doing so, other information is being identical. If it can be shown, usually through a series of F-tests and considering AIC on lagged values of $x_{t}$ (and with lagged values of $y_{t}$ also known), that those $x_{t}$ values provide statistically significant information about future values of $y_{t}$ time series then $x_{t}$ is said to Granger-cause $y_{t}$ i.e. $x_{t}$ can be used to forecast $\mathrm{y}_{\mathrm{t}}$. The pre-condition for applying Granger Causality test is to ascertain the stationarity of the variables in the pair. Engle and Granger (1987) show that if two non-stationary variables are co-integrated, a vector auto-regression in the first differences is unspecified. If the variables are co-integrated, an error-correcting model must be constructed. In the present case, the variables are not co-integrated; therefore, Bivariate Granger causality test is applied at the first difference of the variables. The second requirement for the Granger Causality test is to find out the appropriate lag length for each pair of variables. For this purpose, we used the vector auto regression (VAR) lag order selection method available in Eviews. This technique uses six criteria namely log likelihood value ( $\log \mathrm{L})$, sequential modified likelihood ratio (LR) test statistic, final prediction error (F \& E), AKaike information criterion (AIC), Schwarz information criterion (SC) and Hannan-Quin information criterion (HQ) for choosing the optimal lag length. Among these six criteria, all except the LR statistics are monotonically minimizing functions of lag length and the choice of optimum lag length is at the minimum of the respective function and is denoted as a $*$ associated with it.

Since the time series of exchange rates is stationary or I(0) from the ADF test, the Granger Causality test is performed as follows:

$\Delta \mathrm{N}_{\mathrm{t}}=\alpha_{1}+\beta_{11} \Delta \mathrm{N}_{\mathrm{t}-1}+\beta_{12} \Delta \mathrm{N}_{\mathrm{t}-2}+\ldots+\beta_{1 \mathrm{n}} \Delta \mathrm{N}_{\mathrm{t}-\mathrm{n}}+\gamma_{11} \mathrm{~F}_{-1}+\gamma_{12} \mathrm{~F}_{\mathrm{t}-2}+\ldots+\gamma_{1 \mathrm{n}} \mathrm{F}_{\mathrm{t}-\mathrm{n}}+\varepsilon_{1, \mathrm{t}}$

$\mathrm{F}_{\mathrm{t}}=\alpha_{2}+\beta_{21} \mathrm{~F}_{\mathrm{t}-1}+\beta_{22} \mathrm{~F}_{\mathrm{t}-2}+\ldots+\beta_{2 \mathrm{n}} \mathrm{F}_{\mathrm{t}-\mathrm{n}}+\gamma_{21} \Delta \mathrm{N}_{\mathrm{t}-1}+\gamma_{22} \Delta \mathrm{N}_{\mathrm{t}-2}+\ldots+\gamma_{2 \mathrm{n}} \Delta \mathrm{N}_{\mathrm{t}-\mathrm{n}}+\varepsilon_{2, \mathrm{t}}$

Where $\mathrm{n}$ is a suitably chosen positive integer; $\beta \mathrm{j}$ and $\gamma \mathrm{j}, \mathrm{j}=0,1 \ldots \mathrm{k}$ are parameters and $\alpha$ 's are constant; and $\mathrm{u}_{\mathrm{t}}{ }^{\text {'s }}$ are disturbance terms with zero means and finite variances.

$\left(\Delta \mathrm{N}_{\mathrm{t}}\right.$ is the first difference at time $\mathrm{t}$ of Nifty where the series is non-stationary.)

\section{Empirical Analysis}

As outlined in the methodology, the analysis of the data was conducted in four steps.

First, normality test was applied on both the series to determine the nature of their distributions. For this purpose, Jarque-Bera statistics were computed, which are shown in Table 4.1 along with descriptive statistics for the two series. Skewness value 0 and kurtosis value 3 indicate that the variables are normally distributed. The skewness coefficient, in excess of unity is taken to be fairly extreme [Chou 1969]. High or low kurtosis value indicates extreme leptokurtic or extreme platykurtic [Parkinson 1987]. From the obtained statistics, it is evident that both the variables are non-normally distributed, as the skewness values for Nifty returns and exchange rates are --0.295287 and 0.297429 respectively and the kurtosis values are 4.712687 and 9.096539 respectively.

Second, having affirmed the non-normal distribution of the two variables, the question of stationarity of the two time series posed concerns. Simplest way to check for stationarity is to plot time series graph and observe the trends in mean, variance and autocorrelation. A time series is said to be stationary if its mean and variance are constant over time. The line plots for the two series (log normal value of relatives) are shown in Fig 4.1 and Fig 4.2 respectively. As seen in the plots, for both the series, the mean and variance appear to be constant as the plot trends neither upward nor downward. At the same time, the vertical fluctuations also indicate that the variance, too, is not changing. This hints that stationarity in both the series in their level forms.

Since in addition to visual inspection, formal econometric tests are also needed to unambiguously decide the actual nature of time series, ADF test was performed to check the stationarity of the time series. The results are shown in Table 4.2.

Comparing the obtained ADF statistics for the two variables with the critical values for rejection of hypothesis of existence of unit root, it becomes evident that the obtained statistics for Nifty returns and exchange rates, -9.522362 and -8.078591 respectively, fall behind the critical values even at $1 \%$ significance level $(-3.9887)$ (thus, giving probability values 0.00 ); thereby, leading to the rejection of the hypothesis of unit root for both the series. Hence, it can be safely concluded on the basis of ADF test statistics that stock returns as well as exchange rates are, both, found to be stationary at level form. It may be noted here that as a consequence of stationarity at level form in both the series, Johansen Cointegration test cannot be applied to the variables to determine long-term relationship between them. 
Third, Correlation test was conducted between stock returns and exchange rates. Correlation test can be seen as first indication of the existence of interdependency among time series. Table 4.3 shows the correlation coefficients between stock returns and exchange rates. From the derived statistics, we observe the coefficient of correlation to be -0.088 , which is indicative of negative correlation between the two series. Thus, we may state that the two series are weakly correlated as the coefficient of correlation depicts some interdependency between the two variables. However, correlations may be spurious. The correlation needs to be further verified for the direction of influence by the Granger causality test.

Fourth, to capture the degree and the direction of long term correlation between Nifty returns and exchange rates under study, Granger Causality Test was conducted. Results are presented in table 4.4.From the statistics given in the table, we can deduce that the null hypothesis -"Exchange Rates do not Granger cause Stock returns"cannot be rejected as the obtained f-statistic, 1.60186, fails to fall behind the critical value. However, we can certainly reject the null hypothesis that Stock returns do not Granger cause Exchange series. In other words, the results for the Granger Causality test show that stock returns, clearly, Granger cause the Exchange rates. The causality remains unidirectional. Exchange rates cannot be said to direct the stock returns. Hence, the result is unidirectional causality running from stock returns to exchange rates.

\section{Conclusion}

This research empirically examines the dynamics between the volatility of stock returns and movement of Rupee-Dollar exchange rates, in terms of the extent of interdependency and causality. To begin with, absolute values of data were converted to log normal forms and checked for normality. Application of Jarque-Bera test yielded statistics that affirmed non-normal distribution of both the variables. This posed questions on the stationarity of the two series. Hence subsequently, stationarity of the two series was checked with ADF test and the results showed stationarity at level forms for both the series. Then, the coefficient of correlation between the two variables was computed, which indicated slight negative correlation between them. This made way for determining the direction of influence between the two variables. Hence, Granger Causality test was applied to the two variables, which proved unidirectional causality running from stock returns to exchange rates, that is, an increase in the returns of Nifty caused a decline in the exchange rates but the converse was not found to be true.

\section{References}

Aggarwal, R. (2003). Exchange rates and stock prices: A study of the US capital markets under floating exchange rates. Akron Business and Economic Review, 12, 7-12.

Ajayi, R. A., \& Mougoue, M. (1996). On the dynamic relation between stock prices and Exchange Rates. Journal of Financial Research, 19, 193-207.

Ajayi., R. A., Friedman, J., \& Mehdian, S. M. (1998). On the relationship between stock returns and exchange rates: Test of granger causality. Global Finance Journal, 9 (2) , 241-251.

Babu, M. S., \& Prabheesh, K. (2007). Causal Relationships between Foreign Institutional Investments and stock returns in India. International Journal of Trade and Global Markets, Vol. 1 No. 3/2008, 259-265.

Bahmani-Oskooee, M., \& A.Sohrabian. (1992). Stock Prices and the Effective Exchange Rate of the Dollar. Applied Economics, 24, $459-464$.

C.K.Ma, \& Kao, G. W. (1990). On Exchange Rate Changes and Stock Price Reactions. Journal of Business Finance \& Accounting, 17 , 441-449.

Chakrabarti, R. (2001). FII Flows to India: Nature and Causes. Money and Finance, Vol. 2 Issue 7,Oct-Dec .

Chou, Y. L. (1969). Statistical Analysts. London: Holt Rinehart and Winston.

Dickey, D. A., \& Fuller, W. A. (1981). Likelihood Ratio Statistics for Autoregressive Time Series with a Unit Root. Econometrica, 49, 1057-1072.

Doong, S.-C., Yang, S.-Y., \& Wang, A. T. (2005). The Emerging Relationship and Pricing of Stocks and Exchange Rates: Empirical Evidence from Asian Emerging Markets. Journal of American Academy of Business, Cambridge, 7, (1), 118-123.

Enders, W. (1995). Applied Economic Time Series. New York: Wiley.

Engle, R. F., \& Granger, C. W. (1987). Co-integration and error-correction: Representation, estimation and testing. Econometrica, $55,251-276$.

Erbaykal, E., \& Okuyan, H. A. (2007). Hisse Senedi Fiyatları ile Döviz Kuru ilişkisi:Gelişmekte Olan Ülkeler Üzerine Ampirik Bir Uygulama. BDDK Bankacllık ve Finansal Piyasalar Dergisi, 1(1), 77-89. 
Gordon, J., \& Gupta, P. (2003). Portfolio Flows into India: Do Domestic Fundamentals Matter? IMF Working Paper Number, WP/03/02, 217-229.

Griffin, J. M., Nardari, F., \& Stulz, R. M. (2004). Daily cross-border equity flows:Pushed or pulled? Review of Economics and Statistics, vol. 86, 641-57.

Gujarati, D. N. (2003). Basic Econometrics. McGraw Hill, India.

Ibrahim, M., \& Aziz, M. (2003). Macroeconomic variables and the Malaysian equity market: A rolling through subsamples. Journal of Economic Studies, 30(1), 6-27.

Joseph, N. (2002). Modelling the impacts of interest rate and exchange rate changes on UK Stock Returns. Derivatives Use, Trading \& Regulation, 7(4), 306-323.

Kim, K. (2003). Dollar Exchange Rate and Stock Price: Evidence from Multivariate Cointegration and Error Correction model. Review of Financial Economics, 12, 301-313.

Kurihara, Y. (2006). The Relationship between Exchange Rate and Stock Prices during the Quantitative Easing policy in Japan. International Journal of Business, 11(4), 375-386.

Maysami, R., \& Koh, T. (2000). A Vector Error Correction Model of the Singapore Stock Market. International Review of Economics and Finance, 9:1, 79-96.

Mishra, A. K., Swain, N., \& Malhotra, D. (2007). Volatility Spillover between tock and Foreign Exchange Markets: Indian Evidence. International Journal of Business, 12(3), 343-359.

Morley, B., \& Pentecost, E. (2000). Common Trends and Cycles in G-7 Countries Exchange Rates and Stock Prices. Applied Economic Letters, 7, 7-10.

Naeem, M., \& Abdul, R. (2002). Stock Prices and Exchange Rates: Are they Related? Evidence from South Asian Countries. Department Economics \& Finance, Institute of Business Administration, Karachi.

Najang, \& Seifert, B. (1992). Volatility of exchange rates, interest rates, and stock returns. Journal of Multinational Financial Management, 2, 1-19.

Nieh, C.-C., \& Lee, C.-F. (2001). Dynamic relationship between stock prices and exchange rates for G-7 countries. The Quarterly Review of Economics and Finance, 41, 477-490.

Ozair, A. (2006). Causality Between Stock prices and Exchange Rates: A Case of The United States. Florida Atlantic University, Master of Science Thesis.

Pan, M.-S., Fok, R. C.-W., \& Liu, Y. A. (2007). Dynamic Linkages between exchange rates and stock prices: Evidence from East Asian markets. International Review of Economics and Finance, 16, 503-520.

Parkinson, J. M. (1987). The EMH and the CAPM on the Nairobi Stock Exchange. East African Economic Review, 13, 105-110.

Pethe, A., \& Karnik, A. (2000). Do Indian Stock Markets matter? Stock Market Indices and Macro Economic Variables. Economic and Political Weekly, 35: 5, 349-356.

Phylaktis, Kate, \& Ravazzolo, F. (2005). Stock prices and exchange rate dynamics. Journal of International Money and Finance, 24, 1031-1053.

R.Aggarwal, \& Soenen, L. (1989). Financial Prices as Determinants of Changes in Currency Values. 25th Annual Meetings of Eastern Finance Association. Philadelphia.

Sevuktekin, M., \& Nargelecekenler, M. (2007). Turkiye'de IMKB ve Doviz Kuru Arasındaki Dinamik İlişsinin Belirlenmesi. Turkiye Ekonometri ve Istatistik Kongresi,Inonu Universitesi, Malatya .

Smyth, R., \& Nadha, M. (2003). Bivariate causality between exchange rates and stock prices in South Asia. Applied Economics Letters, 10, 699-704.

Soenen, L., \& Hennigar, E. S. (1988). An Analysis of Exchange Rates and Stock Prices: the U.S. experience U.S. Experience between 1980 and 1986. Akron Business and Economic Review, vol. 19, 7-16.

Stavárek, D. (2005). Stock Prices and Exchange Rates in the EU and the USA: Evidence of their Mutual Interactions. Finance a úvûr-Czech Journal of Economics and Finance, 55, 141-161.

Takeshi, I. (2008, November). The causal relationships in mean and variance between stock returns and Foreign institutional investment in India. IDE Paper Discussion, No. 180 .

Trivedi, P., \& Nair, A. Determinants of FII Investment Inflow to India. 5th Annual conference on Money \& 
Finance in The Indian Economy(January 30 - February 1, 2003), Indira Gandhi Institute of Development Research.

V.Murinde, \& Abdalla, I. S. (1997). Exchange rate and stock price interactions in emerging financial markets: Evidence on India, Korea, Pakistan and the Philippines. Applied Financial Economics, 25-35.

Vygodina, A. V. (2006). Effects of size and international exposure of the US firms on the realtionship between stock prices and exchange rates. Global Finance Journal, 17, 214-223.

$\mathrm{Wu}$, Y. (2000). Stock prices and exchange rates in a VEC model-the case of Singapore in the 1990s. Journal of Economics and Finance, 24(3), 260-274.

Yau, H.-Y., \& Nieh, C.-C. (2006). Interrelationships among stock prices of Taiwan and Japan and NTD/Yen exchange rate . Journal of Asian Economics, 17, 535-552.

\section{Web References}

1. Yahoo Finance: www.yahoofinance.com

2. Wikipedia: www.wikipedia.org

3. Ebsco: search.ebscohost.com

4. Oanda, the currency site : www.oanda.com/convert/fxhistory

\section{Appendix}

Table 4.1. Descriptive Statistics

\begin{tabular}{lll}
\hline \hline & Stock Returns & Exchange Rates \\
\hline Observations & 346 & 346 \\
Mean & -0.002166 & 0.000825 \\
Median & -0.000716 & 0.000216 \\
Maximum & 0.067574 & 0.037868 \\
Minimum & -0.130132 & -0.031866 \\
Std. Deviation & 0.026266 & 0.007346 \\
Skewness & -0.295287 & 0.297429 \\
Kurtosis & 4.712687 & 9.096539 \\
Jarque-Bera & 47.31656 & 540.9370 \\
Probability & 0.000000 & 0.000000 \\
Sum & -0.749533 & 0.285487 \\
Sum Sq Dev. & 0.238025 & 0.018619 \\
Result & Not Normal & Not Normal \\
\hline \hline
\end{tabular}


Table 4.2. Results of Augmented Dickey Fuller Test

Table 4.2.1. ADF On NIFTY Return series

\begin{tabular}{lllll}
\hline \hline ADF Test Statistic & -9.522362 & $1 \%$ & Critical Value* $^{*}$ & -3.9887 \\
& & $5 \%$ & Critical Value & -3.4246 \\
& & $10 \%$ & Critical Value & -3.1351
\end{tabular}

* MacKinnon critical values for rejection of hypothesis of a unit root.

Augmented Dickey-Fuller Test Equation

Dependent Variable: D(RETURN)

Method: Least Squares

Date: 09/01/09 Time: 13:29

Sample(adjusted): 6346

Included observations: 341 after adjusting endpoints

$\begin{array}{lllll}\text { Variable } & \text { Coefficient } & \text { Std. Error } & \text { t-Statistic } & \text { Prob. } \\ \text { RETURN(-1) } & -1.151233 & 0.120898 & -9.522362 & 0.0000 \\ \text { D(RETURN(-1)) } & 0.203932 & 0.104896 & 1.944131 & 0.0527 \\ \text { D(RETURN(-2)) } & 0.187598 & 0.090457 & 2.073897 & 0.0389 \\ \text { D(RETURN(-3)) } & 0.158126 & 0.074293 & 2.128409 & 0.0340 \\ \text { D(RETURN(-4)) } & 0.040233 & 0.054395 & 0.739637 & 0.4600 \\ \text { C } & 0.000113 & 0.002890 & 0.039037 & 0.9689 \\ \text { @ TREND(1) } & -1.45 \mathrm{E}-05 & 1.44 \mathrm{E}-05 & -1.003108 & 0.3165 \\ & & & & \\ \text { R-squared } & 0.479671 & \text { Mean dependent var } & 5.87 \mathrm{E}-05 \\ \text { Adjusted R-squared } & 0.470324 & \text { S.D. dependent var } & 0.035939 \\ \text { S.E. of regression } & 0.026156 & \text { Akaike info criterion } & -4.429171 \\ \text { Sum squared resid } & 0.228499 & \text { Schwarz criterion } & -4.350511 \\ \text { Log likelihood } & 762.1737 & \text { F-statistic } & 51.31694 \\ \text { Durbin-Watson stat } & 2.009118 & \text { Prob(F-statistic) } & 0.000000\end{array}$


Table 4.2.2. ADF on exchange rate series

\begin{tabular}{lllll}
\hline \hline ADF Test Statistic & -8.078591 & $1 \%$ & Critical Value* & -3.9887 \\
& & $5 \%$ & Critical Value & -3.4246 \\
& & $10 \%$ Critical Value & -3.1351 \\
\hline \hline
\end{tabular}

*MacKinnon critical values for rejection of hypothesis of a unit root.

Augmented Dickey-Fuller Test Equation

Dependent Variable: D(EXCHANGE_SERIES)

Method: Least Squares

Date: 09/01/09 Time: 12:48

Sample(adjusted): 6346

Included observations: 341 after adjusting endpoints

\begin{tabular}{|c|c|c|c|c|}
\hline Variable & Coefficient & Std. Error & $\mathrm{t}$-Statistic & Prob. \\
\hline $\begin{array}{l}\text { EXCHANGE_SERIES( } \\
-1)\end{array}$ & -0.907166 & 0.112293 & -8.078591 & 0.0000 \\
\hline $\begin{array}{l}\text { D(EXCHANGE_SERIE } \\
\mathrm{S}(-1))\end{array}$ & 0.063189 & 0.100217 & 0.630524 & 0.5288 \\
\hline $\begin{array}{l}\text { D(EXCHANGE_SERIE } \\
\mathrm{S}(-2))\end{array}$ & -0.005157 & 0.087352 & -0.059036 & 0.9530 \\
\hline $\begin{array}{l}\text { D(EXCHANGE_SERIE } \\
\mathrm{S}(-3))\end{array}$ & 0.004833 & 0.071722 & 0.067382 & 0.9463 \\
\hline $\begin{array}{l}\text { D(EXCHANGE_SERIE } \\
\mathrm{S}(-4))\end{array}$ & -0.025535 & 0.054801 & -0.465963 & 0.6415 \\
\hline $\mathrm{C}$ & $6.77 \mathrm{E}-05$ & 0.000812 & 0.083339 & 0.9336 \\
\hline @ TREND(1) & $3.86 \mathrm{E}-06$ & 4.06E-06 & 0.949718 & 0.3429 \\
\hline R-squared & 0.430331 & \multicolumn{2}{|c|}{ Mean dependent var } & $8.86 \mathrm{E}-06$ \\
\hline Adjusted R-squared & 0.420097 & \multicolumn{2}{|c|}{ S.D. dependent var } & 0.009649 \\
\hline S.E. of regression & 0.007348 & \multicolumn{2}{|c|}{ Akaike info criterion } & -6.968536 \\
\hline Sum squared resid & 0.018032 & \multicolumn{2}{|c|}{ Schwarz criterion } & -6.889875 \\
\hline Log likelihood & 1195.135 & \multicolumn{2}{|c|}{ F-statistic } & 42.05083 \\
\hline Durbin-Watson stat & 1.997013 & \multicolumn{2}{|c|}{ Prob(F-statistic) } & 0.000000 \\
\hline
\end{tabular}

Table 4.3. Correlation Coefficients Matrix

\begin{tabular}{l|l|l}
\hline \hline & Nifty Returns & Exchange Rates \\
\hline \hline Nifty Returns & 1.000000 & -0.087787 \\
Exchange Rates & -0.087787 & 1.000000 \\
\hline \hline
\end{tabular}


Table 4.4. Results of Granger Causality Test

\begin{tabular}{|c|c|c|}
\hline Null Hypothesis & F-Statistic & Probability \\
\hline Stock Returns does not Granger Cause Exchange Series & 1.60186 & 0.15904 \\
\hline Exchange Series does not Granger Cause Stock Returns & 16.2319 & $2.6 \mathrm{E}-14$ \\
\hline
\end{tabular}

Table 4.5. Inference from Granger Causality Test

\begin{tabular}{l|l|l}
\hline \hline & Nifty Returns & Exchange Rates \\
\hline \hline Nifty Returns & ---- & $\boldsymbol{\uparrow}$ \\
Exchange Rates & & ---- \\
\hline \hline
\end{tabular}

$\uparrow$ Denotes Granger Causality, running from one side to another

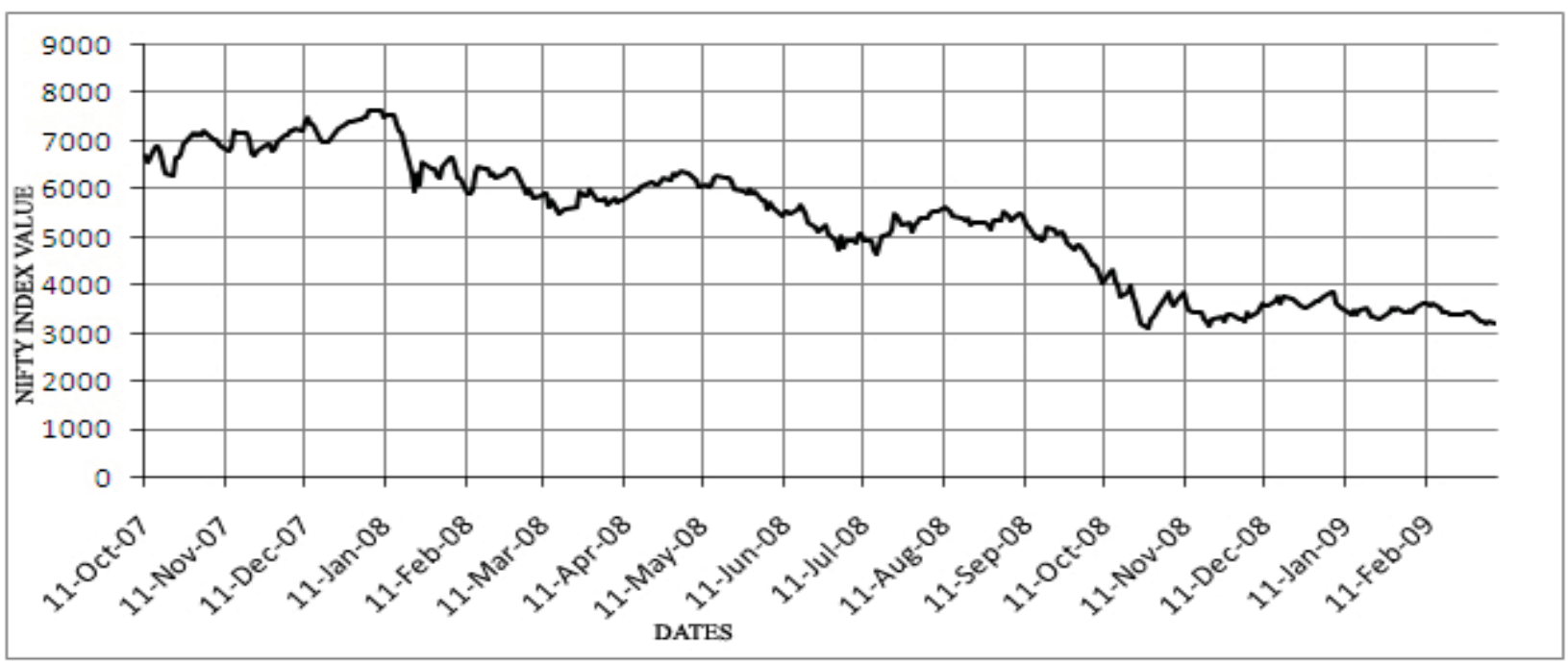

Figure 3.1. Line Plot of Nifty Indices Data

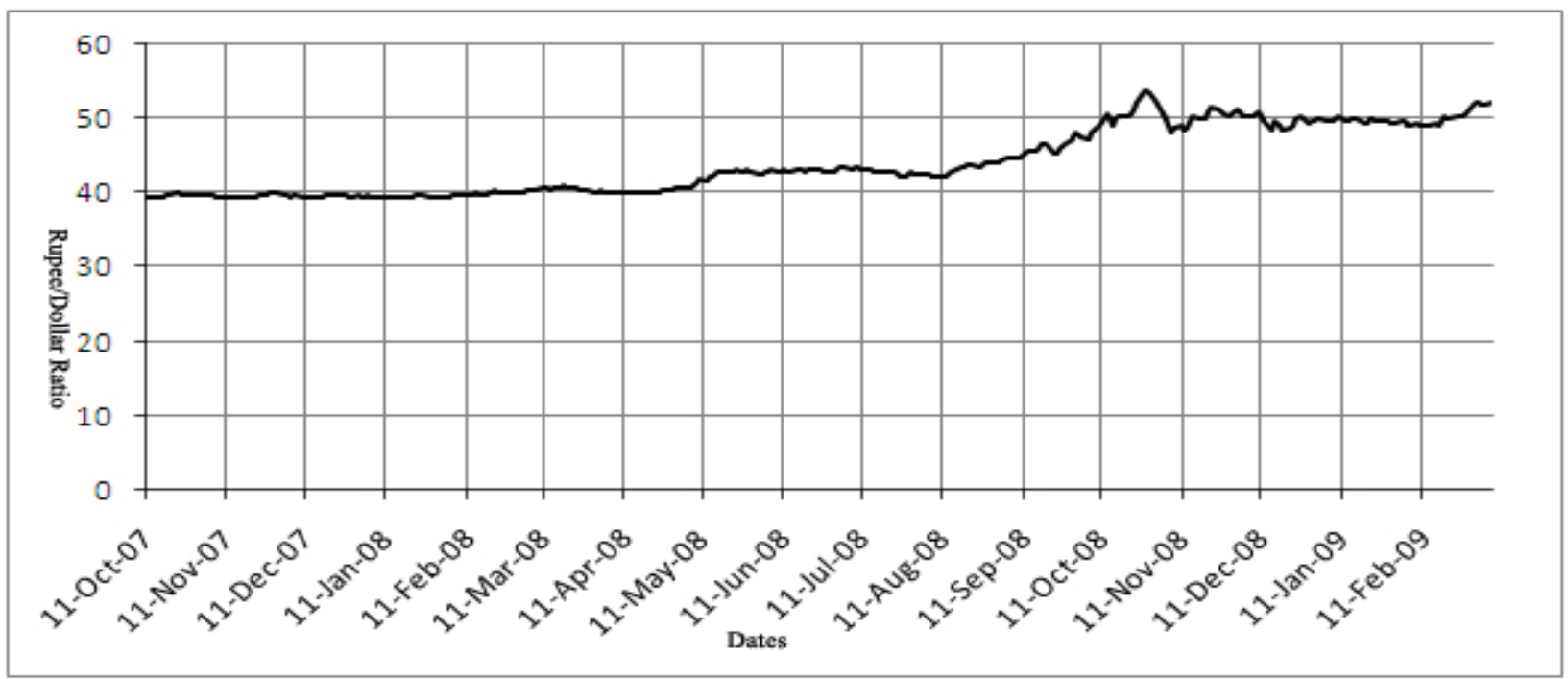

Figure 3.2. Line Plot of Exchange Rates Data 


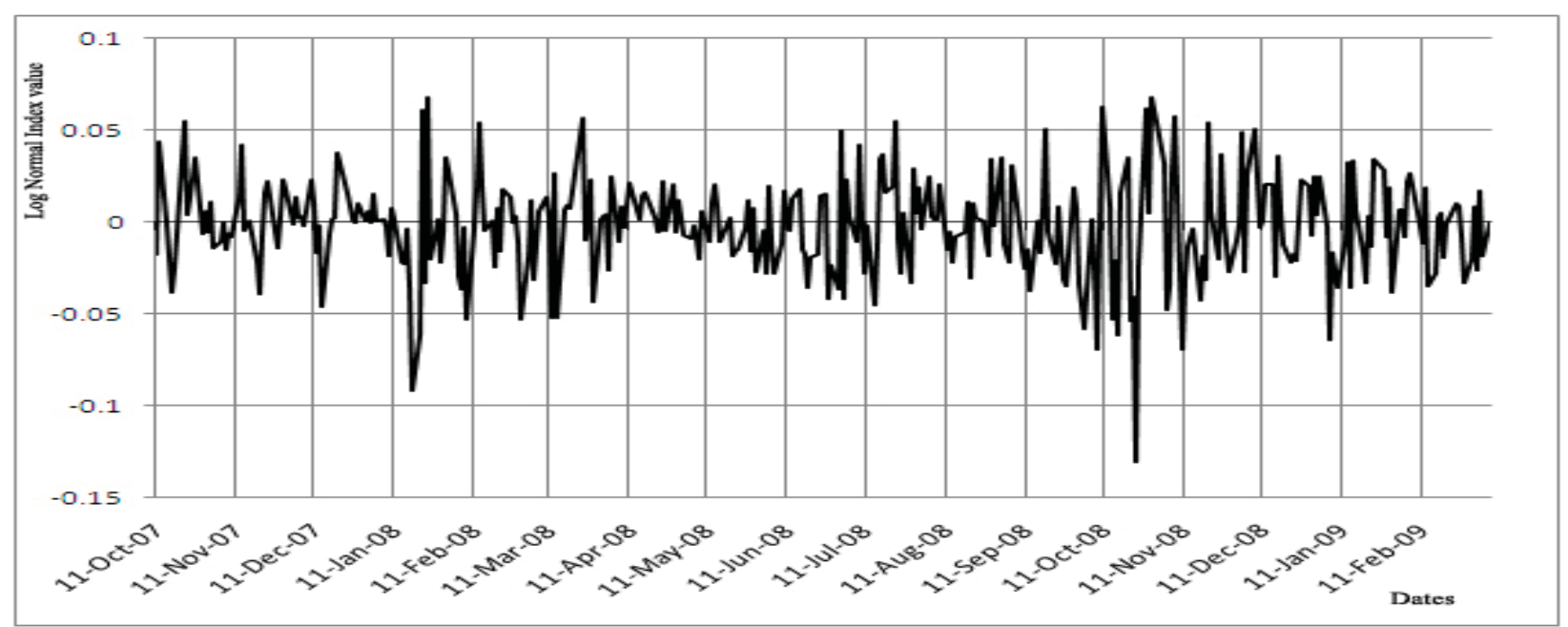

Figure 4.1. Line Plot of Nifty Returns

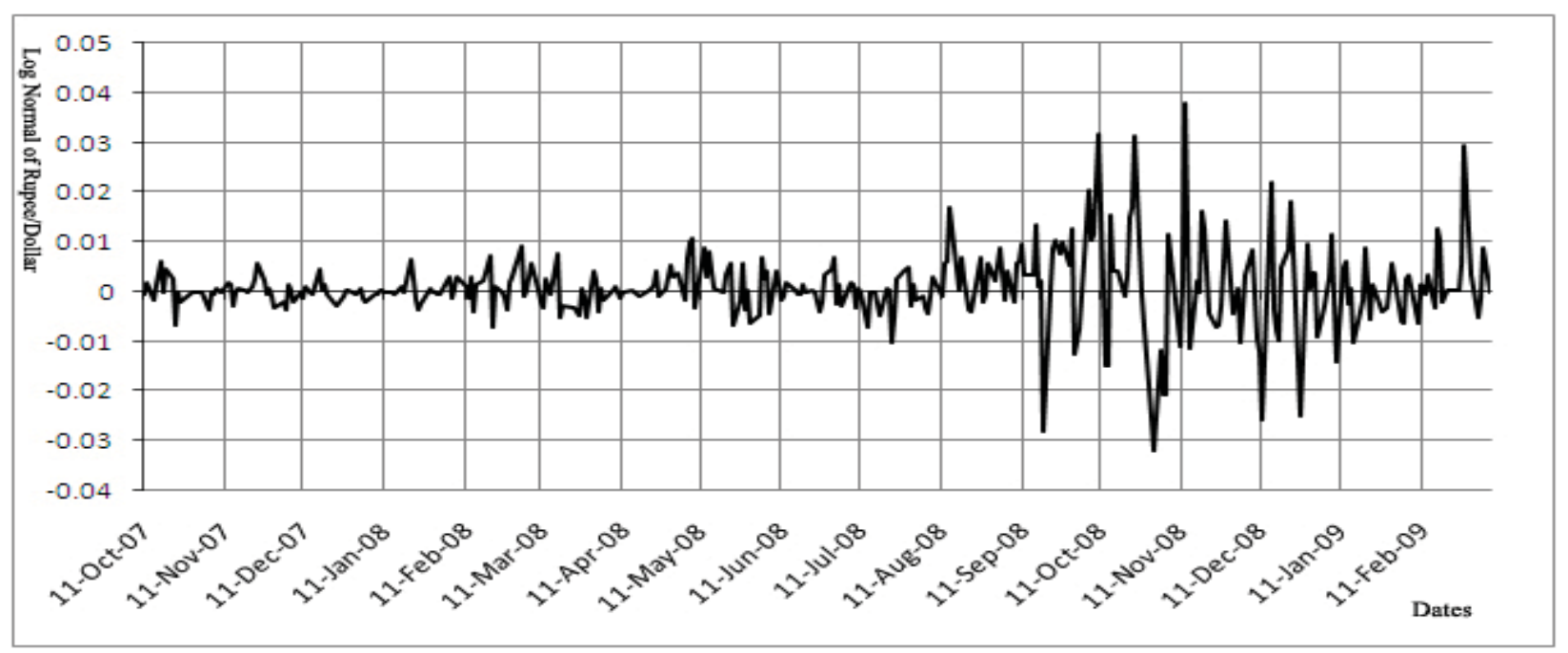

Figure 4.2. Line Plot of Log Normal Exchange Rates 